\title{
Accounting
}

\section{CEO characteristics and earnings management}

\section{Saja Yousef Qawasmeh ${ }^{a}$ and Mohammad Jamal Azzam ${ }^{b^{*}}$}

${ }^{a}$ Independent Researcher, Irbid, Jordan

${ }^{b}$ Department of Accounting, Yarmouk University, Irbid, Jordan

\section{H R O N I C L E \\ A B S T R A C T}

Article history:

Received: April 29, 2020

Received in revised format: July 302020

Accepted: August 10, 2020

Available online:

August 10, 2020

Keywords:

Earnings Management

CEO Characteristics

Amman Stock Exchange

\begin{abstract}
This study investigates the association between the CEO characteristics and EM practices of nonfinancial firms on the Amman Stock Exchange. Based on 1,277 firm-year observations from 2010 to 2018, four characteristics were examined: tenure, age, experience, and ownership. The results show that the EM practices of CEOs were higher in the early years of their service compared with later years. The results also show that CEOs' ownership plays an important role in increasing the magnitude of EM to maximize their compensation. However, the age and expertise of CEOs did not have any role in either increasing or decreasing discretionary accruals levels. This study contributes to the literature by supporting the perspective that CEOs are highly motivated to alter earnings when they start leading their firms, to send positive signals to stakeholders.
\end{abstract}

\section{Introduction}

Financial reporting aims to reflect the actual financial position of firms, which in turn helps the users of financial statements make their decisions based on relevant information. Financial information, however, can be distorted or manipulated through several accounting treatments exercised by firms' managers to meet specific benchmarks (i.e. meet analysts' forecasts). These treatments are called earnings management (EM), where managers may try to mislead stakeholders regarding the real financial performance of their firms (Deegan, 2014). A firm's chief executive officer (CEO) has the authority to access all relevant information regarding the firm's operations and activities. This superiority of information increases his/her ability to manage earnings. Previous studies have presented three types of incentives where CEOs may have to exercise their discretion over reported earnings. The first is capital market incentives, where managers have an incentive to alter their reported earnings to meet analysts' forecasts, or to maintain performance by increasing report earnings or reversing a decrease in earnings (Gunny, 2010). Second is regulatory and tax incentives, where CEOs may adjust earnings to avoid the costs associated with governmental regulations (Chen \& Zhang, 2014). The third type of incentive pertaining to EM is contractual incentives, where CEOs may manipulate earnings to maximise their own compensation (Ali \& Zhang, 2015). The contractual incentives motivate the current study to investigate the Jordanian capital market and test whether firms' CEOs engage in EM practices to maximise their own benefits. More interestingly, there are very limited studies worldwide regarding the extent and direction of EM during CEOs' service. Furthermore, there are limited studies that aim to analyse EM behaviour in a developing context like Jordan, given that

* Corresponding author. Tel.: +962778577286

E-mail address: moh.azzam@yu.edu.jo (M. J. Azzam) 
the generalisability of findings from a developed country context to a developing one is questionable, given the marked differences in their business and regulatory environments.

\section{Theoretical Framework}

The literature has used several terms to describe accounting discretion, like earnings manipulation, earnings inflating and deflating, and positive and negative discretionary accruals. The most commonly used term in the literature, however, is EM. Healy and Wahlen (1999, p. 368) define EM as follows:

"Earnings management occurs when managers use judgment in financial reporting and in structuring transaction to alter financial reports to either mislead some stakeholders about the underlying economic performance of the company or to influence contractual outcomes that depend on reported accounting numbers".

This definition highlights the importance of the accounting judgment that CEOs make when they prepare financial statements. Such judgments include estimating the salvage value and expected life of long-term assets, selecting the appropriate method to measure inventory, determining the limits of research and development expenditures and, more importantly, managing credit sales. Positive Accounting Theory (PAT) argues that all individual actions are driven by self-interest. Thus, CEOs may choose the accounting treatments that are most likely lead to an increase in their firm's earnings. This, in turn, maximises their privileges. Watts and Zimmerman (1986, p. 208) state that, "Ceteris paribus, managers of firms with bonus plans are more likely to choose accounting procedures that shift reported earnings from future periods to the current period". Indeed, the literature has provided empirical evidence that EM is largely observed in firms where CEOs' compensation depends on financial performance. One of the early and well-known studies on the relationship between CEOs' compensation and EM was conducted by Healy (1985). The study shows that when their bonus plan did not reach the maximum limit, they tried to adopt upward EM; otherwise, they adopted a downward EM. As mentioned above, the basic assumption of PAT is that individuals are selfinterested. This assumption is evident in the case of managers' contracts, where managers can change their firm's earnings to increase their compensation, especially when such compensation is mainly based on reported earnings (Hossain \& Monroe, 2015; Sun, 2014). Agency Theory (AT) also argues that there is a conflict of interests between firms' management and shareholders (Jensen \& Mecklin, 1976). The core issue in AT is information asymmetry, - where certain information becomes available for and can be accessed by some individuals that is not available for others - (Deegan, 2014). CEOs, therefore, may try to exploit the superiority of information they have to alter firms' earnings to maximise their own benefits.

\section{Literature Review and Hypotheses Development}

\subsection{CEO Tenure and Earnings Management}

There is widespread concern about whether there is an association between CEO tenure and the magnitude of firms' EM. Empirically, several previous studies provide evidence that the extent of EM is greater in the early years of CEOs' service compared with their later years. One of the early studies on this issue was conducted by Pourciau (1993), who found that CEOs in the first year of their work were most likely to maximise reported earnings because new CEOs sought to show that the financial performance of the previous CEO was very poor. Indeed, Oyer (2008) and Axelson and Bond (2009) argue that at the beginning of their service, CEOs avoid reporting a reduction in earnings because they may classify as 'low ability' managers. Using US-based data, Ali and Zhang (2015) show that newly appointed CEOs have been proved to use real and accruals EM to increase earnings, specifically in the early three years. In a different vein, Kalyta (2009) finds that in the pre-retirement period there is evidence of income-increasing EM, especially when CEO compensation is based on firm performance. Consistent with this result, Verkek (2012) states that CEOs have less time to prove themselves and therefore they manage earnings upward in the last year of their tenure. This, in turn, may boost their reputation and compensation. Interestingly, some researchers (like Zhang, 2009) distinguish between short-tenured and long-tenured CEOs and find that long-tenured CEOs report earnings less aggressively than short-tenured ones. Based on the previous discussion, the following hypothesis is formulated:

\section{$H_{1}$ : The extent of EM in the early years of CEOs' service will be higher compared with their last years.}

\subsection{CEO Age and Earnings Management}

CEOs' reporting practices may change over the course of their career. For example, Davidson et al. (2007) find that firms whose executives were approaching retirement age had significant discretionary accruals levels in the year prior to retirement. Isidro and Gonçalves (2011) also find that when the CEO was older and near the age of retirement, EM behaviour increased, especially when the firm had a dual leadership structure and thus the horizon problem might occur (Dechow \& Sloan, 1991). 
Some researchers, like Cornett et al. (2008), have presented a counter-argument regarding CEO age, proposing that older CEOs may be linked with lower discretionary accruals levels. This is most likely because newly appointed CEOs, especially those with limited experience, may have a significant incentive to engage in EM practices at an initial stage. Another stream of research aims to explain the relationship between the decision-making process and CEO age. For example, Serfling (2012) argues that young CEOs invest less than older ones because the younger CEOs are more prone to take risks. Of equal importance, Santoso (2014) asserts that younger CEOs are expected to report more EM than older CEOs, based on the argument that older CEOs might be less aggressive in their behaviour. Taken together, there is no consensus in the literature that EM increases/decreases with the passage of time for CEOs. This study, however, follows the perspective which expects to observe more EM practices as the CEO's age increases. Thus, the following hypothesis is formulated:

$H_{2}$ : There is a positive association between $\mathrm{CEO}$ age and EM.

\subsection{CEO Experience and Earnings Management}

There is no universally agreed measurement of CEOs' experience due to the different proxies that researchers employ to measure it and then examine its impact on the magnitude of firms' EM. Indeed, prior research uses different proxies, such as education, financial expertise, previous positions in other firms and holding professional certificates in accounting. For example, Xie et al. (2003) find that firms where managers had a managerial background were associated with lower levels of EM behaviour. Qi et al. (2018) report a significant negative link between both accrual-based and real EM and the educational level of CEOs/CFOs, which in turn decreases the quality of financial reporting. Using a different proxy, Zouari et al. (2012) investigate the relationship between CEO expertise and EM practices. They find that financial experience is positively associated with a CEO's tendency to use aggressive EM. Jiang, Zhu and Huang (2013) find that, while CEOs with financial experience are less engaged in real EM, there is no conclusive evidence that they manage earnings via accrual-based EM. Their findings suggest that CEOs with financial experience provide more accurate financial reporting compared with other CEOs that do not hold such experience. Gounopoulos and Pham (2018) measure CEOs' financial experience as those who have previous employment in banks, investment firms or large audit firms, and find that such CEOs are less likely to manage earnings through both accruals and real EM. To summarise, there is no general agreement on the best measure of CEO experience. Moreover, prior studies provide contradictory findings pertaining to the association between CEO experience and the extent of EM. This study, however, follows the perspective in the literature that CEOs may use their financial experience to manage earnings to meet specific earnings targets, rather than maximising shareholders' wealth. Hence, the following hypothesis is formulated:

\section{$H_{3}$ : There is a positive association between CEO experience and EM.}

\subsection{CEO Ownership and Earnings Management}

CEO's ownership is one of the most important factors that may affect a CEO's ability to manipulate their firm's reported earnings. This suggests that, as the percentage of shares held by CEOs increases, the incentive for them to engage in accounting misbehaviour also increases (Sharma \& Kuang, 2014). Therefore, more managerial ownership may encourage managers to use discretionary accruals to improve earnings. Thus, the value of their stocks, especially in the short-term, is maximised (Yang, Lai \& Tan, 2008). Several previous studies - such as those by Al-Fayoumi, Abuzayed and Alexander (2010), Mitani (2010) and Kazemiana and Sanusib (2015) - have provided empirical evidence that firms with higher managerial ownership are associated with more EM activities. This is because the greater ownership held by CEOs will provide them with deeper entrenchment and therefore, more room for opportunistic behaviour. While most prior research documents the positive relationship between CEO ownership and EM, there are also a limited number of researchers who provide a counter-argument - that a CEO with a low level of ownership will engage more in EM. Indeed, O'Callaghan et al. (2018) and Amir et al. (2019) find that there is a negative association between managerial ownership and discretionary accruals. They argue that the low percentage of ownership held by CEOs provides them with an incentive to alter earnings, especially when their firms face poor financial performance. The current study, therefore, follows many previous studies and formulates the following hypothesis:

\section{$H_{4}:$ There is a positive association between CEO Ownership and EM.}

\section{Research Methodology}

This study uses non-financial firms listed on the Amman Stock Exchange (ASE) in the period 2010 to 2018. Financial firms are excluded because they have a different financial reporting regime. As shown in Table 1, the total number of firms on ASE for the selected period is 2,084 firm-year observations. For the purposes of this study, 663 observations are excluded as financial firms. Another 144 observations are also excluded due to missing data. The final sample, therefore, includes 1,277 firm-year observations. The main reason behind selecting the period from 2010 to 2018 is that this period allows the current study to examine the behaviour of CEOs' discretionary choices in the aftermath of the latest global financial crisis, which happened between 2008 and 2009. In other words, it tests whether CEOs are engaged more in EM practices to alter earnings to overcome the negative consequences of the crisis, especially in the early years of CEOs' service. 


\section{Table 1}

Sample selection criteria for listed firms on the ASE from 2010 to 2018

\begin{tabular}{|c|c|c|c|c|c|c|c|c|c|c|}
\hline Description & 2010 & 2011 & 2012 & 2013 & 2014 & 2015 & 2016 & 2017 & 2018 & Total \\
\hline $\begin{array}{l}\text { Firm Listed on ASE } \\
\text { Excluded: }\end{array}$ & 277 & 247 & 243 & 240 & 236 & 228 & 224 & 194 & 195 & 2084 \\
\hline Financial Firms & 78 & 79 & 76 & 74 & 73 & 74 & 72 & 73 & 64 & 663 \\
\hline Missing Data & 43 & 15 & 15 & 19 & 20 & 13 & 14 & 0 & 5 & 144 \\
\hline Final Sample & 156 & 153 & 152 & 147 & 143 & 141 & 138 & 121 & 126 & 1277 \\
\hline
\end{tabular}

This study uses an accruals approach to estimate EM using one of the most used models in the literature- the performance matched discretionary accruals model (PMDAM), which was introduced by Kothari, Leone and Wasley (2005). Following this model, the current study estimates discretionary accruals for firms within the same 2-digit industry code for each year from 2010 to 2018, as follows:

where:

$$
\frac{T A C_{i t}}{T A_{i t-1}}=a_{0}+a_{1}\left(\frac{1}{T A_{i t-1}}\right)+a_{2}\left(\frac{\Delta R E V_{i t}-\Delta R E C_{i t}}{T A_{i t-1}}\right)+a_{3}\left(\frac{P P E_{i t}}{T A_{i t-1}}\right)+a_{4} R O A_{i t}+\varepsilon_{i t}
$$

$T A C_{i t}=$ total accruals for firm $i$ in year $t$;

$T A_{i t-1}=$ total assets at the beginning of the year for firm $i$ in year $t$;

$\triangle R E V_{i t}=$ change in revenues from the current year and previous year for firm $i$ in year $t$;

$\triangle R E C_{i t}=$ change in receivables from the current year and previous year for firm $i$ in year $t$;

$P P E_{i t} \quad=$ gross property, plant and equipment for firm $i$ in year $t$;

$R O A_{i t}=$ net income divided by total assets from the current year for firm $i$ in year $t$;

$\varepsilon_{i t} \quad=$ error term; and

$a_{1}-a_{4}=$ firm specific parameters.

Total accruals are computed using the balance sheet approach. The coefficients $\left(a_{1}, a_{2}, a_{3}\right.$ and $\left.a_{4}\right)$ are then used to estimate non-discretionary accruals $\left(N D A_{i t}\right)$. Finally, discretionary accruals $\left(D A_{i t}\right)$, as the proxy for EM in the current study, are calculated as the difference between total accruals $\left(T A C_{i t}\right)$ and non-discretionary accruals $\left(N D A_{i t}\right)$. Independent variables are measured as follows: CEO Tenure is measured using a dummy variable that takes the value of one if the CEO's service in the firm is less than the mean, and zero otherwise. CEO Age is measured by the CEO's age at the end of the year. CEO Experience is measured using a dummy variable that takes the value of one if the CEO has experience in preparing or auditing financial statements, or has been a financial analyst, or has a professional accounting certificate, and zero otherwise. CEO Ownership is measured as the percentage of shares owned by a firm's CEO compared to the total number of shares issued. This study also controls for firm size, leverage, firm age, ROA and book to market ratio. Firm Size is measured by total assets at the end of a firm's year. Leverage is measured as the ratio of total debt to total equity. Firm Age is measured by the time length of a firm's establishment. ROA is measured as the ratio of net income to total assets. $B M$ is measured as the ratio of book value of equity to market value of equity. Therefore, the association between CEOs' characteristics and EM is examined using the following regression equation:

$$
\begin{gathered}
\text { EM }_{i t}=\beta_{0}+\beta_{1} \text { CEO.TENURE } \\
+\beta_{6} A G E_{i t}+\beta_{7} \text { CEO.AGE } E_{i t}+\beta_{8} L E V_{i t}+\beta_{9} S I Z E+E X P E R I E N C E_{i t}+\beta_{4} C E O . O W N E R S H I P_{i t}+\beta_{5} R O A_{i t} \\
+\beta_{i t}
\end{gathered}
$$

Table 2

Summary of variables and their measurement

\begin{tabular}{lll}
\hline Description & Variable name & Measurement \\
\hline Dependent variable: & Earnings management & The absolute value of discretionary accruals \\
& & \\
Independent variables: & CEO tenure & The number of years being served as a CEO \\
CEO.TENURE & CEO age & The CEO's age at the beginning of the year \\
CEO.AGE & CEO experience & The CEO's financial experience at the beginning of the year \\
CEO.EXPERIENCE & CEO ownership & The percentage of stocks owned by the CEO at the beginning of the year \\
CEO.OWNERSHIP & & \\
& & \\
Control variables: & Return on assets & The ratio of net income to total assets \\
ROA & Firm age & The time length of a firm's establishment \\
AGE & Book to market ratio & The ratio of book value of equity to market value of equity \\
BM & Leverage & The ratio of total debt to total equity \\
LEV & Firm size & The total assets at the beginning of the year \\
SIZE & & + \\
\hline
\end{tabular}


Table 3 shows that the mean of the absolute value of discretionary accruals (ABSDA) is 0.54 with a median of 0.31 . This implies that firms' CEOs were engaged more in EM activities to conceal any bad financial performances in the aftermath of the 2008 financial crisis. Of equal importance, CEOs are also highly motivated to adjust reported earnings, especially in the early years of their service, to provide shareholders and any other stakeholders with a good image of themselves. The table also shows that while, on average, CEOs served for three and half years in their positions (CEO Tenure), the mean value recorded for their age (CEO Age) was 52 years. Interestingly, the minimum age recorded for a firm's CEO was 22 years, which in turn may direct the criticisms to the board of directors with regard to whether such a CEO has the required experience to direct a listed firm on the ASE. However, the statistics reported in Table 3 may minimise the importance of the criticisms about having a young CEO. This is because, on average, 97 percent of listed firms have a CEO with financial experience (CEO Experience).

Table 3

Descriptive statistics for dependent, independent and control variables

\begin{tabular}{|c|c|c|c|c|c|}
\hline Variable & Observations & Mean & Median & Min & Max \\
\hline ABSDA & 1.277 & 0.544 & 0.312 & 0.001 & 3.827 \\
\hline CEO Tenure & 1.277 & 3.482 & 3.000 & 1.000 & 9.000 \\
\hline CEO Age & 1.277 & 52.42 & 52.00 & 22.00 & 83.00 \\
\hline CEO Experience & 1.277 & 0.971 & 1.000 & 0.000 & 1.000 \\
\hline CEO Ownership & 1.277 & 0.034 & 0.003 & 0.000 & 0.692 \\
\hline ROA & 1.277 & -0.017 & 0.008 & -4.832 & 5.010 \\
\hline AGE & 1.277 & 21.60 & 19.00 & 1.000 & 81.00 \\
\hline BM & 1.277 & 1.305 & 1.097 & -3.773 & 5.880 \\
\hline LEV & 1.277 & 0.331 & 0.261 & -1.800 & 3.624 \\
\hline $\begin{array}{l}\text { SIZE } \\
\text { (in million } \$ U S \text { ) }\end{array}$ & 1.277 & 90.14 & 29.71 & 0.014 & 2.492 \\
\hline
\end{tabular}

All variables were defined above in Table 2 .

Regarding ownership (CEO Ownership), the statistics show that the mean value recorded is approximately 3.5 percent. This low level of ownership is highly expected, as the bulk of CEOs of listed firms on the ASE received cash compensation, thus no stock options were awarded. Table 3 also reports descriptive statistics for control variables. The mean values recorded for return on assets $(R O A)$, leverage $(L E V)$ and book to market ratio $(B M)$ are around $(-0.01),(0.33)$ and (1.30), respectively. Firm age $(A G E)$ is reported at 21.6 years. Finally, the mean value of firm size (SIZE), measured by total assets, is approximately $\$ U S 90$ million, which in turn indicates that most firms listed on the ASE are relatively small.

Table 4 reports the correlation matrix of the current study's variables. The literature argues that the problem of multicollinearity exists when the association between two variables reaches 70 percent and more. As shown in the table, the highest correlation recorded is 26.3 percent between leverage ( $L E V)$ and total assets (SIZE). Notwithstanding that this correlation does not represent a threat to the regression results; it is highly expected as large firms are most likely to have the ability to gain funds from banks and other financial institutions. Overall, the problem of multicollinearity does not exist in the current study.

Table 4

Spearman correlation matrix

\begin{tabular}{|c|c|c|c|c|c|c|c|c|c|}
\hline & CEO Tenure & CEO Age & CEO Experience & $\begin{array}{c}\text { CEO } \\
\text { Ownership }\end{array}$ & ROA & AGE & BM & LEV & SIZE \\
\hline CEO Tenure & 1.000 & & & & & & & & \\
\hline CEO Age & $0.233^{*}$ & 1.000 & & & & & & & \\
\hline CEO Experience & -0.015 & $-0.102 *$ & 1.000 & & & & & & \\
\hline CEO Ownership & $0.192 *$ & $0.253^{*}$ & $-0.056^{*}$ & 1.000 & & & & & \\
\hline ROA & $0.116^{*}$ & $0.152 *$ & -0.052 & $0.153^{*}$ & 1.000 & & & & \\
\hline AGE & $0.169^{*}$ & $0.210^{*}$ & $0.068^{*}$ & $-0.108^{*}$ & $0.157 *$ & 1.000 & & & \\
\hline BM & 0.045 & -0.031 & -0.007 & -0.025 & $-0.214^{*}$ & $-0.140 *$ & 1.000 & & \\
\hline LEV & -0.032 & 0.017 & 0.038 & $-0.166^{*}$ & $-0.170 *$ & $0.248^{*}$ & $-0.139 *$ & 1.000 & \\
\hline SIZE & -0.036 & 0.054 & $0.069 *$ & $-0.081 *$ & $0.239 *$ & $0.185^{*}$ & -0.048 & $0.263^{*}$ & 1.000 \\
\hline
\end{tabular}

The symbol $(*)$ denotes significance at 1 percent in a two-tailed test. All variables were defined above in Table 2.

Table 5 reports the results of fixed effect regression for the association between CEO characteristics and EM. The current study assumes that CEOs will engage in EM activities more in the early years of their service compared with the later years. The 
results reported in Table 5 support this assumption and show a positive and significant association (coefficient $=0.137$ and $\mathrm{p}<$ 0.01 ) between the early years of a CEO's service (CEO Tenure) and the magnitude of absolute value of EM (ABSDA). This result lends credence to the argument that CEOs are self-interested, and thus they are tacking and implementing decisions that lead to maximise their privileges irrespective of whether such decisions are aligned with stockholders' interests. This result is also consistent with that reported by Ali and Zhang (2015) in the US context. They find that even high-profile CEOs will inflate earnings to avoid reporting a poor performance in the early years of their service, even if such a poor outcome is not caused by the current management's decisions. Based on the current study's results, $H_{l}$ is accepted. Inconsistent with the current study's proposition, Table 5 reveals that there is a positive but insignificant association between CEO age (CEO Age), CEO experience (CEO Experience) and ABSDA, suggesting that age and experience are not considered effective factors that motivate/limit a CEO's ability to manipulate reported earnings. This indicates that what is important in motivating CEOs to alter their firm's earnings is not their age or experience, but rather the period in which they are serving (i.e. early period or later period). Therefore, this study rejects $\mathrm{H}_{2}$ and $\mathrm{H}_{3}$.

\section{Table 5}

Regression results of the association between CEO characteristics and ABSDA

\begin{tabular}{|c|c|c|c|c|}
\hline ABSDA & & Coefficient & T-value & Probability \\
\hline CEO Tenure & & 0.1371 & 2.89 & 0.004 \\
\hline CEO Age & & 0.0024 & 0.84 & 0.400 \\
\hline CEO Experience & & 0.1580 & 0.88 & 0.378 \\
\hline CEO Ownership & & 1.0174 & 3.39 & 0.001 \\
\hline $\mathrm{ROA}$ & & -0.0272 & -0.52 & 0.606 \\
\hline AGE & & 0.0515 & 6.40 & 0.000 \\
\hline BM & & -0.0111 & -0.42 & 0.676 \\
\hline LEV & & -0.0469 & -0.53 & 0.593 \\
\hline SIZE & & -1.6100 & -5.09 & 0.000 \\
\hline Constant & & -0.8359 & -2.71 & 0.007 \\
\hline Adjusted $R^{2}$ & 21.5 & & & \\
\hline No. of observations & 1,277 & & & \\
\hline
\end{tabular}

Notes: This table presents the results of fixed effect regression of the association between CEO characteristics and EM. The sample includes 1,277 firm-year observations of listed firms on the ASE from 2010 to 2018. The dependent variable is the absolute value of discretionary accruals (ABSDA) estimated from the performance matched discretionary accruals model (2005). Independent and control variables were defined above in Table 2.

In terms of the link between CEO ownership (CEO Ownership) and ABSDA, the reported results show a positive and significant association between them (coefficient $=1.017$ and $\mathrm{p}<0.01$ ). Notwithstanding that the mean value recorded for CEO ownership in the Jordanian context is relatively very small (see Table 3), ownership is found to play a pivotal role in motivating CEOs to adjust earnings. One possible justification of this result is that most firms' CEOs are interested in near-term earnings, and thus they inflate current earnings to receive more dividends or sell their stocks at high prices. This result is also in line with the findings of several studies in different contexts, like those of Kazemiana and Sanusib (2015), Sharma and Kuang (2014), Mitani (2010) and Cheng and Warfield (2005). Based on this conclusion, $H_{4}$ is accepted. Table 5 also reports the results for control variables. Firm age $(A G E)$ is found to be significantly linked with ABSDA, indicating that older firms are engaged more in EM activities compared with newly listed firms. This is because older firms are interested in maintaining performance to keep investors' confidence in their operations. By contrast, large firms (SIZE) are engaged less in EM practices, probably because such firms are subject to more monitoring, especially from governmental agencies and external auditors. Other control variables - namely return on assets $(R O A)$, book to market ratio $(B M)$ and leverage $(L E V)$ - are found to be insignificantly associated with the extent of firms' EM.

To further validate the current study's results, a separate regression is run to examine the association between CEO characteristics and positive EM (i.e. income-increasing EM). Indeed, conventional wisdom suggests that firms' CEOs will manage earnings upward in the early years of their service to send positive signals to shareholders about the financial performance of firms. This in turn leads to an improved reputation and financial rewards. To address this issue, signed EM is divided into positive EM (i.e. 763 firm-year observations) and negative EM (i.e. 514 firm-year observations) and then positive EM is examined separately. The reported results in Table 6 are approximately like the primary findings reported in Table 5. Specifically, CEOs inflated earnings in the early years of their service in listed firms compared with their later years. A slight change, however, is observed for CEO ownership. While the coefficient is still positive, its association with positive EM becomes statistically insignificant. In terms of control variables, the same significance and direction are found. Overall, the use of positive EM instead of ABSDA produces similar findings, which in turn lend credence to the primary findings reported above in Table 5. 
Table 6

Regression results of the association between CEO characteristics and positive EM

\begin{tabular}{|c|c|c|c|c|}
\hline Positive EM & & Coefficient & T-value & Probability \\
\hline CEO Tenure & & 0.1519 & 2.14 & 0.033 \\
\hline CEO Age & & 0.0037 & 0.86 & 0.392 \\
\hline CEO Experience & & 0.4535 & 1.53 & 0.184 \\
\hline CEO Ownership & & 0.3755 & 0.79 & 0.429 \\
\hline ROA & & 0.0001 & 0.00 & 0.999 \\
\hline AGE & & 0.0497 & 4.25 & 0.000 \\
\hline BM & & -0.0266 & -0.63 & 0.526 \\
\hline LEV & & -0.1406 & -0.83 & 0.409 \\
\hline SIZE & & -1.1990 & -2.73 & 0.007 \\
\hline Constant & & -1.1513 & -2.51 & 0.012 \\
\hline $\begin{array}{l}\text { Adjusted } R^{2} \\
\text { No. of observations }\end{array}$ & $\begin{array}{l}14.8 \\
763\end{array}$ & & & \\
\hline
\end{tabular}

Notes: This table presents the results of fixed effect regression of the association between CEO characteristics and positive EM. The sample includes 763 firmyear observations of listed firms on the ASE from 2010 to 2018. The dependent variable is positive discretionary accruals estimated from the performance matched discretionary accruals model (2005). Independent and control variables were defined above in Table 2.

\section{Conclusion}

EM activities are one of the most important issues that may represent a threat to the authenticity of financial reporting. Investors and other stakeholders depend on firms' financial positions to take their investing, financing, or lending decisions. Therefore, when firms' earnings are manipulated, stakeholders may face financial difficulties, and thus their confidence regarding the integrity of financial reporting will be eroded.

Prior research argues that it is very important for any empirical study that aims to examine EM behaviour to determine the potential incentive behind EM practices. The current study investigates the association between CEOs' characteristics (i.e. tenure, age, experience, and ownership) and the magnitude of EM. It is expected that CEOs will try to manage earnings in the early years of their service compared with the later years. Additionally, older CEOs with more experience and ownership are predicted to be positively linked with EM activities.

A panel data set of 1,277 firm-year observations of listed firms on the ASE is analysed. The results show that EM is largely observed in the early years of CEOs' service compared with their later years. This result supports the perspective in the literature that CEOs are highly motivated to alter earnings when they start leading their firms, in an attempt to send positive signals to the stakeholders. This, in turn, corroborates CEOs' reputation and, by default, maximises their financial compensation. The results also show the statistically significant role of managerial ownership in increasing the EM practices exercised by CEOs. This is most likely because CEOs are interested in short-term earnings and EM activities can maximise such earnings. Finally, CEOs' age and experience are not found to play any role in either increasing or decreasing discretionary accruals levels. Future research, however, could use a qualitative approach (i.e. interviews) to investigate the association between CEO characteristics and EM. A qualitative approach could help to acquire information that cannot be reached using the quantitative approach.

\section{References}

Al-Fayoumi, N., Abuzayed, B. \& Alexander, D. (2010). Ownership structure and earnings management in emerging markets: The case of Jordan. International Research Journal of Finance and Economics, 38(1), 28-47.

Ali, A. \& Zhang, W. (2015). CEO tenure and earnings management. Journal of Accounting and Economics, 59(1), 60-79.

Amir, A., Shaari, H. \& Ariff, A. (2019). Ownership structure and real earnings management in Malaysian corporation. International Conference on Economics, Entrepreneurship and Management.

Axelson, U. \& Bond, P. (2009). Investment bank career. Working Paper. Stockholm School of Economics, University of Pennsylvania.

Chen, J. \& Zhang, H. (2014). The impact of the corporate governance code on earnings management: evidence from Chinese listed companies. European Financial Management, 20(3), 596-632.

Cheng, Q. \& Warfield, T. D. (2005). Equity incentives and earnings management. The Accounting Review, 80(2), $441-476$.

Cornett, M., Marcus, J. \& Tehranian, H. (2008). Corporate governance and pay-for performance: The impact of earnings management. Journal of Financial Economics, 1(1), 357-373.

Davidson, W., Xie, B., Xu, W. \& Ning, Y. (2007). The influence of executive age, career horizon and incentives on pre-turnover earnings management. Journal of Management \& Governance, 1(1), 45-60.

Dechow, P. \& Sloan, R. (1991). Executive incentives and the horizon problem: An empirical investigation. Journal of Accounting and Economics, 14(1), 51-89. 
Deegan, M. (2014). Financial Accounting Theory. 4th edn, McGraw-Hill Education, North Ryde, N.S.W, Australia.

Gounopoulos, D. \& Pham, H. (2018). Financial expert CEOs and earnings management around initial public offerings. The International Journal of Accounting, 53(2), 102-117.

Gunny, A. (2010). The relation between earnings management using real activities manipulation and future performance: Evidence from meeting earnings benchmarks. Contemporary Accounting Research, 2(3), 855-888.

Healy, P. (1985). The effect of bonus schemes on accounting decisions. Journal of Accounting and Economics, 7(1), 85-107.

Healy, P. \& Wahlen, M. (1999). A review of the earnings management literature and its implications for standard setting. Accounting Horizons, 13(4), 365-383.

Hossain, S. \& Monroe, S. (2015). Chief financial officers' short and long-term incentive based compensation and earnings management. Australian Accounting Review, 25(3), 279-291.

Isidro, H. \& Gonçalves, L. (2011). Earnings management and CEO characteristics in Portuguese firms. Corporate Ownership and Control, 1(1), 87-95.

Jeanjean, T. \& Stolowy, H. (2008). Do accounting standards matter? An exploratory analysis of earnings management before and after IFRS adoption. Journal of Accounting and Public Policy, 27(6), 480-494.

Jensen, M. \& Meckling, H. (1976). Theory of the firm: Managerial behavior, agency costs and ownership structure. Journal of accounting and economics, 3(1), 305-360.

Jiang, F., Zhu, B. \& Huang, J. (2013). CEO's financial experience and earnings management. Journal of Multinational Financial Management, 23(3), 134-145.

Kalyta, P. (2009). Accounting discretion, horizon problem, and CEO retirement benefits. The Accounting Review, 84(5), 15531573.

Kazemian, S. \& Sanusi, Z. (2015). Earnings management and ownership structure. Procedia Economics and Finance, 31(1), 618-624.

Kothari, P., Leone, J. \& Wasley, E. (2005). Performance matched discretionary accrual measures, Journal of Accounting and Economics, 39(1), 163-197.

Marai, A. \& Pavlović, V. (2014). An overview of earnings management measurement approaches: Development and evaluation. Facta Universitatis, Series: Economics and Organization, 11(1), 21-36.

Mitani, H. (2010). Additional evidence on earnings management and corporate governance, FSA Research Review, 6(1), 1-22.

O’Callaghan, S., Ashton, J. \& Hodgkinson, L. (2018). Earnings management and managerial ownership in private firms. Journal of Applied Accounting Research, 19(4), 648-668.

Oyer, P. (2008). The making of an investment banker: Stock market shocks, career choice, and lifetime income. Journal of Finance, 63(1), 2601-2628.

Pourciau, S. (1993). Earnings management and non-routine executive changes. Journal of Accounting and Economics, 16(3), 317-336.

Qi, B., Lin, J., Tian, G. \& Lewis, X. (2018). The impact of top management team characteristics on the choice of earnings management strategies: Evidence from China. Accounting Horizons, 32(1), 143-164.

Santoso, R. (2014). CEO characteristics and earnings management. Doctoral dissertation, University of GadjahMada.

Serfling, M. (2012). CEO age, underinvestment, and agency costs. College of Management, University of Arizona.

Sharma, D. \& Kuang, C. (2014). Voluntary audit committee characteristics, incentives, and aggressive earnings management: Evidence from New Zealand. International Journal of Auditing, 18(1), 76-89.

Sun, B. (2014). Executive compensation and earnings management under moral hazard, Journal of Economic Dynamics and Control, 41(1), 276-290.

Verkerk, S. (2012). Are CEO changes related to earnings management? Erasmus University Rotterdam, Zwijndrecht.

Watts, L. \& Zimmerman, L. (1986). Positive Accounting Theory, Prentice-Hall, Englewood Cliffs, N.J, USA.

Xie, B., Davidson, N. \& DaDalt, J. (2003). Earnings management and corporate governance: The role of the board and the audit committee. Journal of Corporate Finance, 9(3), 295-316.

Yang, Y., Lai, N. \& Leing Tan, B. (2008). Managerial ownership structure and earnings management. Journal of Financial Reporting and Accounting, 6(1), 35-53.

Zhang, W. (2009). CEO tenure and earnings quality. School of Management, University of Texas.

Zouari, Z., Lakhal, F. \& Nekhili, M. (2012). Do CEO's characteristics affect earnings management? Evidence from France. International Journal of Innovation and Applied Studies, 12(4), 801-819.

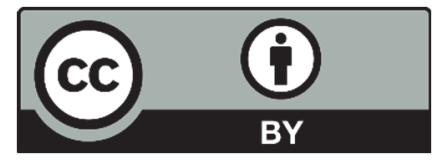

(C) 2020 by the authors; licensee Growing Science, Canada. This is an open access article distributed under the terms and conditions of the Creative Commons Attribution (CC-BY) license (http://creativecommons.org/licenses/by/4.0/). 